\title{
TANGGAPAN MASYARAKAT KARO DI BERASTAGI TERHADAP PERUBAHAN AYO-AYO PADA BANGUNAN OBJEK WISATA TAHURA
}

\author{
Mhd. Try Adhitia ${ }^{1^{*}}$, Nelson Tarigan ${ }^{2 *}$ \\ Program Studi Pendidikan Seni Rupa, Jurusan Seni Rupa, Fakultas Bahasa dan Seni \\ Universitas Negeri Medan \\ E-mail : tryadhitia@gmail.com
}

\begin{abstract}
ABSTRAK
Latar Belakang penelitian ini adalah untuk mengetahui perubahan apa saja yang terjadi pada ayo-ayo bangunan objek wisata Tahura dan pendapat masyarakat Karo di Berastagi terhadap perubahan tersebut. Tujuan penelitian ini adalah untuk mengetahui perubahan bentuk, warna dan ornamen ayo-ayo pada bangunan objek wisata Tahura serta pendapat masyarakat Karo di Berastagi terhadap perubahan tersebut.Populasi yang diambil dalam penelitian ini adalah 1 bangunan objek wisata Tahura dan sampel yang diambil sebanyak 4 bidang ayoayo. Metode penelitian yang digunakan adalah metode kualitatif dan teknik pengumpulan data menggunakan kajian pustaka, observasi lapangan dan dokumentasi, serta wawancara dengan menguraikan perbandingan antara objek yang diteliti dengan sumber-sumber buku dan pendapat ahli, lalu wawancara sebagai cara untuk mengambil tanggapan masyarakat terhadap objek yang diteliti. Ayo-ayo pada bangunan objek wisata Tahura mengalami perubahan pada bahan, bentuk, warna dan ornamen. Perubahan tersebut sudah terlalu jauh dari ayo-ayo yang asli. Hasil temuan peneliti menunjukkan bahwa, perubahan ayo-ayo pada bangunan Tahura tidak hanya terjadi secara umum saja, tetapi secara detail juga. Perubahan tersebut mengakibatkan pengetahuan untuk ayo-ayo yang asli semakin kabur.
\end{abstract}

Kata Kunci : Tanggapan Masyarakat, Perubahan. 


\section{PENDAHULUAN}

Saat ini telah banyak bangunan modern yang menyerap unsur bangunan rumah adat Karo, khususnya pada bagian atap dan bangunan tersebut milik pemerintah. Hal ini dikarenakan upaya pemerintah dalam mendirikan bangunan, tetap ada muatan lokal didalamnya. Akan tetapi dalam pengaplikasiannya ayo-ayo tersebut dibuat jauh dari kaidah yang aslinya. Seperti bentuk dasar ayo-ayo yang seharusnya segitiga sama kaki dirubah menjadi segitiga sama sisi, hal ini tentu saja mempengaruhi muatan ornamen dan proporsi tiap ornamennya.

Tanggapan masyarakat akan hal seperti ini tentunya sangat berpengaruh pada kualitas seni yang dihadirkan. Respon masyarakat Karo pada seni lokal sangat dibutuhkan karena semakin berkembangnya teknologi dan masuknya budaya asing pastinya berpengaruh besar pada hasil budayanya, salah satunya ayo-ayo.

. Perubahan ayo-ayo yang diungkap penulis melalui sumbersumber yang relevan akan diberi tanggapan oleh masyarakat Karo. Tanggapan yang telah dikumpulkan nantinya akan menjadi sebuah penilaian terhadap perubahan ayoayo tersebut. Perubahan itu bisa menjadi hal yang positif maupun negatif dari penilaian masyarakat.

Berdasarkan latar belakang, maka identifikasi masalah sebagai berikut:
1. Sudah tepatkah pemakaian arsitektur tradisional yang diadaptasi dari rumah adat Karo?

2. Bagaimana pengaruh media digital terhadap hasil pembuatan ayo-ayo?

3. Apa yang telah berubah dari ayo-ayo Tahura?

4. Bagaimana bentuk dasar sebuah ayo-ayo?

5. Ornamen dan Warna apa saja yang ada dalam ayo-ayo?

6. Bagaimana tanggapan masyarakat di Berastagi terhadap perubahan ayo-ayo?

7. Sejauh apa pemahaman mereka dengan perubahan teknik, warna, dan bentuk pada ayo-ayo?

Melihat beberapa cakupan masalah di atas, maka masalah dibatasi pada:

1. Perubahan yang terjadi pada ayo-ayo Tahura dan tanggapan masyarakat Karo di Berastagi terhadap perubahan ayo-ayo yang berada di lokasi wisata Taman Hutan Raya (Tahura), Berastagi.

Melalui pembatasan masalah, kemudian dirumuskan sebagai berikut:

1. Perubahan apa saja yang terjadi pada ayo-ayo di bangunan objek wisata Tahura lalu Bagaimana tanggapan masyarakat Karo di Berastagi terhadap perubahan ornamen ayo-ayo 
yang diterapkan pada gedung Taman Hutan Raya (Tahura)?

Tujuan penelitian ini adalah:

1. Untuk mengetahui perubahan apa saja yang terdapat ayoayo Tahura dan tanggapan masyarakat Karo terhadap perubahan ornamen ayo-ayo tersebut.

2. Mengetahui ornamen apa saja yang telah berubah pada ayoayo di gedung Tahura

3. Menyalurkan pendapat masyarakat Karo terhadap perubahan ornamen pada ayo-ayo.

Manfaat penelitian yang diharapkan adalah:

1. Melestarikan nilai budi luhur serta nilai estetis yang terkandung dalam kesenian suku Karo

2. Pertimbangan nilai visual dalam membuat atau pengembangan rumah adat Karo.

3. Penambahan bahan ajar ornamen ayo-ayo pada mata pelajaran muatan lokal di sekolah terutama yang berada di Tanah Karo

\section{KAJIAN PUSTAKA}

\section{Pengertian Tanggapan}

Sebagaimana dijelaskan Suryabrata (1989 : 36) bahwa "tanggapan adalah bayangan yang tinggal dalam ingatan setelah melakukan pengamatan". Dari pendapat ini dapat dipahami bahwa yang dimaksud tanggapan adalah bayangan yang berupa kesan-kesan yang ada dalam ingatan seseorang yaitu hasil dari pengamatan terhadap suatu objek tersebut sudah lepas dari ruang dan waktu pengamatan, dalam arti pengamatan sudah berlangsung.

\section{Pengertian Masyarakat}

(2015:55) menyatakan "masyarakat adalah sekelompok manusia yang telah hidup dan bekerja bersama cukup lama sehingga dapat mengatur diri mereka, dan menganggap kumpulan mereka sebagai suatu kesatuan sosial dengan batasbatas yang dirumuskan secara jelas".

\section{Masyarakat Karo}

Masyarakat Karo adalah seluruh penduduk yang mendiami wilayah Kabupaten Karo. Wilayah ini penduduk aslinya ataupun suku yang mendominasinya adalah suku Karo. Dahulunya Suku Karo sendiri berbentuk kerajaan yang tersebar tidak hanya di kabupaten tanah Karo (sekarang) tetapi ada juga di Deli Serdang hingga Langkat.

Suku Karo adalah salah satu suku bangsa yang mendiami Dataran Tinggi Karo, Sumatera Utara, Indonesia. Suku ini merupakan salah satu suku terbesar dalam Sumatera Utara. Nama suku ini dijadikan salah satu nama Kabupaten di salah satu wilayah yang mereka diami (Dataran Tinggi Karo) yaitu 
Tanah Karo yang terletak di Kabupaten Karo.

Menurut $r$ Ginting
$\begin{aligned} & \text { (2014,1-2)" masyarakat Karo } \\ & \text { menempati }\end{aligned}$ dataran tinggi Karo
dan disebut sebagai Taneh Karo.
Pengertian Taneh $r$ Karo
sebenarnya bukan hanya
mencakup orang Karo yang
berdiam di daerah Kabupaten
Karo sekarang saja. Melainkan
mencakup juga orang-orang Karo
yang sudah lama berdiam atau
menetap di daerah garis besar
Karo, jauh sebelum Belanda
menjajah wilayah asli suku Karo
seperti Kabupaten Deli Serdang,
Langkat, Simalungun, Dairi,
Aceh Tenggara, Kotamadya
Binjai dan Ibukota Provinsi yaitu
Medan".

Penulis berfokus pada masyarakat yang mendiami Tanah Karo, yang lebih tepatnya Berastagi sebagai pemilik budaya Karo sendiri untuk dijadikan pemberi tanggapan

\section{Perubahan Visual}

Kategori transformasi dibagi menjadi empat berdasarkan sifatnya, yaitu:

1. Transformasi topological (geometri)

Bentuk geometri yang tetap, tidak berubah, bahkan jika bentuknya sendiri dirubah tidak ada permukaan yang dirusak atau berubah

2. Transformasi gramatika hiasan (ornamental)

Dilakukan dengan translation (menggeser), rotation (memutar), reflection

(mencerminkan), dan inversion

(menjungkirbalikkan, pembalikan)

3. Transformasi reversal (kebalikan) Pembalikan citra pada figure objek yang akan ditransformasi dimana citra objek dirubah menjadi citra sebaliknya

4.Transformasi

distortion (merancukan)

Kebebasan perancang dalam beraktivitas

Transformasi yang dapat digunakan adalah transformasi gramatika hiasan dan transformasi distortion. (Laseau, 1986:-, Kurniati, 2015:3)

\section{Pengertian, Jenis, dan Unsur Ornamen}

\section{a. Pengertian Ornamen}

S.P. Gustami (1980:4) dalam bukunya seni ornamen Indonesia menyatakan pengertian ragam hias sebagai berikut:

"Ragam hias adalah komponen produk seni yang ditambahkan atau sengaja dibuat untuk tujuan sebagai hiasan. Disamping itu tugasnya yang emplisit menyangkut segi-segi kemudahan,untuk menambah indahnya barang sehingga lebih bagus dan lebih menarik, baik dari segi spiritual maupun material finansial."
b. Jenis-jenis Ornamen
1) Pola berbentuk manusia
2) Pola berbentuk hewan 


$\begin{array}{rlr}\text { 3) } & \text { Pola } & \text { berbentuk } \\ & \text { raksasa } & \\ \text { 4) } & \text { Pola } & \text { berbentuk } \\ & \text { tumbuhan } & \\ \text { 5) } & \text { Pola } & \text { berbentuk } \\ & \text { geometris } & \\ \text { 6) } & \text { Pola } & \text { berbentuk } \\ & \text { kosmos atau alam }\end{array}$

c. Unsur-unsur Ornamen
1) Garis
2) Bidang
3) Bentuk
4) Warna
5) Tekstur
6) Ukuran
7) Irama
8) Pengulangan
9) Kesatuan

\section{Ornamen Karo}

Ornamen dalam bahasa Karo sering disebut gerga atau ukirukiren. Gerga di dalam Kamus KaroIndonesia (Prinst 2002:211) adalah gambar, lukisan, hiasan, ukir-ukiran, pada rumah adat.

\section{Pengertian Ayo-ayo}

Menurut kamus Karo-Indonesia (Prinst,2002:40) "ayo adalah muka, kepala sebelah depan, hadapan bagian atas rumah adat berbentuk segitiga yang letaknya dihadapan". Masih dari sumber yang sama, ayoayo adalah anyaman berbentuk segitiga yang dipasang pada bagian depan atas rumah

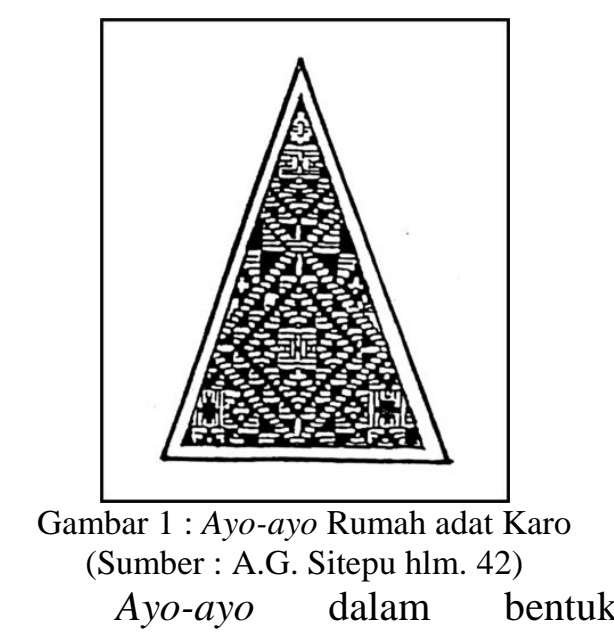

sebenarnya sekarang ini dapat kita lihat pada bangunan rumah adat (rumah gugung) di komplek Gereja Inkulturatif Berastagi. Walaupun bangunan rumah adat tersebut baru dipindahkan tempatkan dan direnovasi, tetapi renovasi yang dilakukan adalah untuk mengembalikan ciri khas rumah adat Karo dahulu dan dalam pengerjaannya sesuai dengan sumber-sumber buku serta diawasi pemuka adat Karo. Sehingga rumah gugung adalah bentuk asli rumah adat Karo. (G.Kriswanto, wawancara pribadi, 30 Januari, 2017)

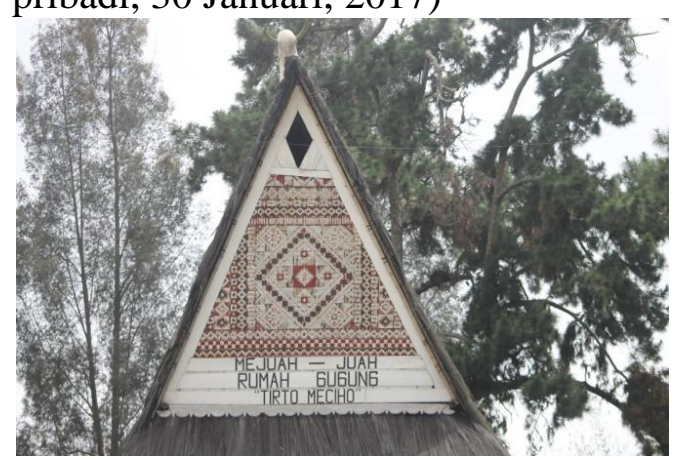

Gambar 2 : ayo-ayo Rumah Gugung (Dokumentasi Pribadi : Mhd. Try Adhitia)

8. Fungsi dan Makna Ayo-ayo Berdasarkan peletakannya pada bagian atas rumah (ayo-ayo) berbentuk segitiga sama kaki yang melambangkan simbol dari tatanan kehidupan masyarakat Karo yaitu 
rakut sitelu, letak pemasangan yang dibuat miring juga telah memberikan pesan dan makna yang ada pada tatanan kehidupan masyarakat Karo. Hal ini juga mencerminkan bahwa hubungan kekerabatan dijunjung tinggi dan dijaga kehormatannya. Hiasan ini melambangkan kedudukan rakut sitelu.

Cara pemasangan ayo-ayo ini, sama dengan dinding rumah adat, yaitu dipasang miring. Keadaan yang demikian menggambarkan kerendahan hati dari orang yang menempatinya khususnya dan masyarakat Karo umumnya, juga dalam halm ini dianjurkan supaya lebih dahulu melihat diri sendiri baru membicarakan orang lain. (Sitanggang, 1992)

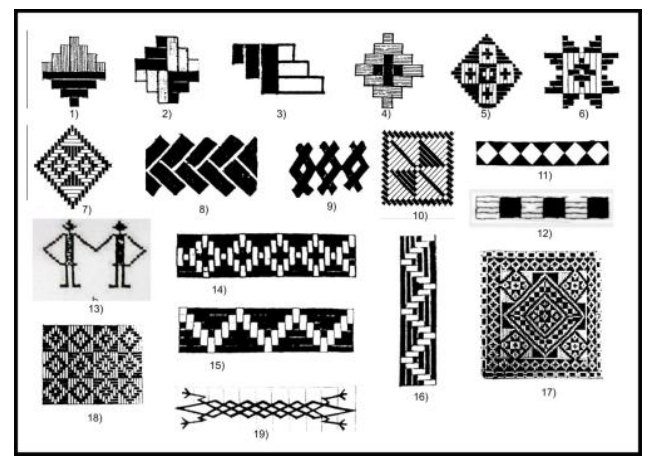

Gambar $2.3: 1)$ embun sikawiten, 2) piseren kambing, 3) bak-bak tenggiang, 4) tampune-tampune, 5) lumut-lumut lawit, 6) bunga gundur, 7) mata-mata lembu, 8) duri nikan, 9) tampuk-tampuk pinang, 10) ser-ser sigembal, 11) pakau-pakau, 12) baleng-baleng, 13) raksasa, 14) anjak-anjak beru ginting, 15) pancung-pancung cekala, 16) embun merkabun-kabun, 18) bunga gundur sitelenen, 19) pengeret-ret (Sumber : A.G Sitepu hlm. 34-41)
9. Perubahan Ornamen Ayoayo Pada Bangunan Objek Wisata Taman Hutan Hutan Raya di Berastagi

Secara garis besar terdapat perubahan pada ayo-ayo bangunan objek wisata Tahura yaitu :

a. Bentuk ayo-ayo pada bangunan objek wisata Tahura Kab.Karo sangat menyalahi bentuk yang sebenarnya, bentuk ayo-ayo pada bangunan tersebut yaitu segitiga sama sisi.

b. Bahan/media : Bahan yang dipakai pada ayo-ayo bangunan tersebut terbuatdari triplek yang dicat sedemikian rupa.

c. Ornamen : ornamen yang dipakai pada ayo-ayo bangunan tersebut yaitu, bunga gundur, tampunetampune, raksasa, cekili kambing, dan sebagian besar ornamen adalah hasil kretifitas tukang yang membuatnya.

d. Warna : warna yang dipakai yaitu merah, hijau, putih dan hitam.

\section{B. Kerangka Konseptual}

Konsentrasi penulis pada penelitian ini adalah mengungkap perubahan ayo-ayo pada bangunan objek wisata Tahura Berastagi, dan apa tanggapan masyarakat Karo sendiri. yang diketahui pada penelitian Desnalri Sinulingga, ayoayo di bangunan objek wisata Tahura 
telah banyak berubah dan menyalahi aturan-aturan bentuk dan ornamen.

Ayo-ayo pada bangunan objek wisata Tahura Berastagi dibuat dengan cetak digital yaitu berbahan MMT sedangkan seharusnya memakai papan ataupun anyaman bamboo yang lebih popular digunakan oleh pengrajin ayo pada umumnya. Ayo-ayo tersebut berbentuk segitiga sama sisi sedangkan seharusnya berbentuk segitiga sama kaki. Ornamen yang terdapat pada ayo-ayo tersebut sebagian besar hasil dari kreatifitas tukang pembvuatnya. Beberapa ornamen yang terdapat pada ayo-ayo itu adalah bunga gundur, tampunetampune, raksasa, pengeret-ret, dan cekili kambing sedangkan seharusnya kurang lebih ada 15 ornamen pada satu ayo-ayo.

Atas dasar itu penulis ingin melihat bagaimana tanggapan masyarakat Karo itu sendiri terhadap ayo-ayo yang telah mengalami perubahan tersebut.

\section{METODOLOGI PENELITIAN}

\section{Tempat, Waktu Penelitian, Populasi, dan Sampel \\ Penelitian dilaksanakan di} Berastagi. Secara teknis, kegiatan penelitian dilaksanakan pada Januari 2017 hingga April 2017.

Populasi dalam penelitian ini adalah bangunan utama objek wisata Tahura. Teknik pengambilan sampelnya adalah sampling purposive yaitu pengabilan sampel berdasarkan pertimbangan tertentu. Sampel pada penelitian ini adalah 4 (empat) buah ayo-ayo pada bangunan utama objek wisata Tahura.

Pada penelitian ini instrumen penelitian yang digunakan adalah wawancara, catatan, perekam suara, dan kamera. Teknik pengumpulan datanya adalah kajian pustaka, observasi lapanagan dan dokumentasi, serta wawancara. Wawancara pada penelitian ini mengambil 20 (dua puluh) narasumber berdasarkan strata yaitu : pemuka adat, pemerintahan, pemerhati seni, pendidikan, seniman, organisasi, komunitas, dan penduduk biasa. Teknik analisis data yang digunakan adalah analisis deskriptif kualitatif, yaitu membuat deskripsi atau gambaran yang sejelas-jelasnya mengenai objek yang diteliti, berdasarkan data-data yang tampak sebagaimana adanya, dan menerangkan secara sistematis, faktual dan cermat akan fakta yang ada dilapangan.

\section{HASIL PENELITIAN DAN PEMBAHASAN}

Hasil Penelitian

\section{Data Penelitian}

1. Perubahan Bentuk Dasar Ayo-ayo

a. Perbandingan ayo-ayo bagian depan

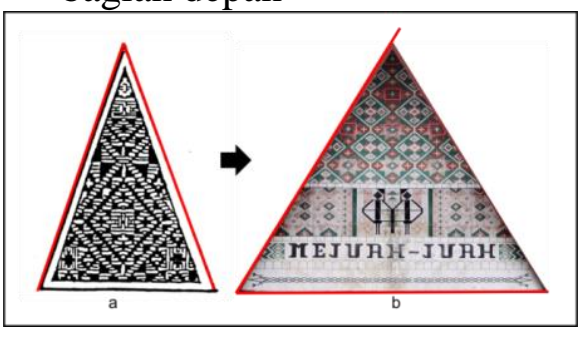

Gambar 4.1 : Perbandingan Ayoayo buku A.G. Sitepu dengan ayo- 
ayo Tahura bagian depan (Sumber :

A.G Sitepu dan Mhd.Try Adhitia)

b. Perbandingan ayo-ayo bagian belakang

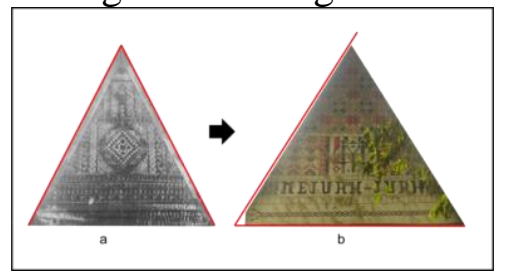

Gambar 4.2 : Perbandingan Ayoayo colectie tropenmuseum dengan ayo-ayo Tahura bagian belakang (Sumber : colectie tropenmuseum dan Mhd. Try Adhitia)

c. Perbandingan ayo-ayo bagian kiri

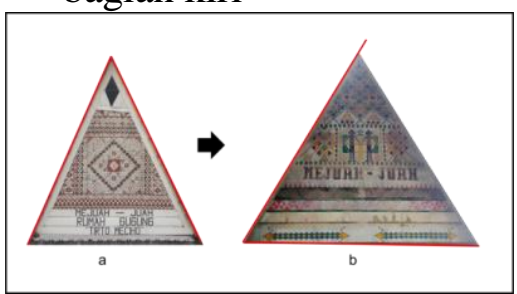

Gambar 4.3 : Perbandingan ayoayo di Gereja Inkulturatif dengan ayo-ayo Tahura bagian kiri

Dokumentasi Pribadi : Mhd. Try Adhitia (2016)

d. Perbandingan ayo-ayo bagian kanan

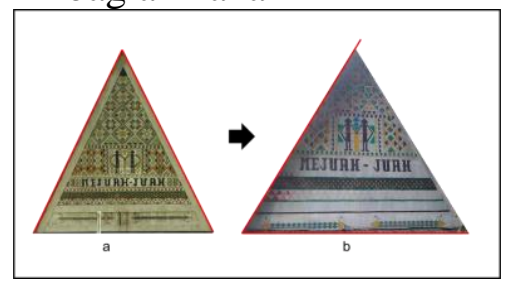

Gambar 4.4 : Perbandingan ayoayo museum Desa Lingga dengan ayo-ayo Tahura bagian kanan

(Dokumentasi Pribadi : Mhd. Try Adhitia)

Dari sejumlah perbandingan bentuk ayo-ayo yang telah dibandingkan, maka akan dijelaskan beberapa perubahan yang terjadi menunjukkan adanya berbagai variasi perancangannya yang masih menunjukkan ciri khas bentuk segitiga sebagai bentuk dasarnya. Namun ada juga yang ditemukan perubahan bentuk dasar pada ayoayo ini menjadi fatal karena sudah menyalahi aturan pada ayo-ayo asli yaitu berbentuk segitiga sama kaki dengan bagian alas lebih kecil dibandingkan dua sisi lainnya. Ayoayo yang dibuat dengan segitiga sama sisi ataupun sama kaki tetapi sisi alasnya lebih lebar dibandingkan dua sisi lainnya tidak lagi mencerminkan rakut sitelu seutuhnya. Kesan yang dihasilkan pada bentuk ayo-ayo yang lebih menjulang akan berbeda dengan ayoayo yang berbentuk melebar. Karena bentuknya melebar, juga mempengaruhi banyaknya ornamen yang ditempatkan pada bidang ayoayo tersebut.

\section{Bahan dan Penyesuaian Kemiringan ayo-ayo}

Pada dasarnya ayo-ayo dibuat dari anyaman bambu. Bambu yang digunakan berumur kurang lebih 3 tahun bernama dalam bahasa Karo biasanya disebut buluh regen.

Ayo-ayo di Tahura tidak memakai bahan bambu dalam pembuatannya, tetapi menggunakan bahan spanduk MMT (flexi korea). Perubahan bahan ini menyebabkan daya tahan ayo-ayo itu buruk. Bentuk dan warnanya cepat hilang apalagi terkena cahaya matahari langsung dan air hujan. 


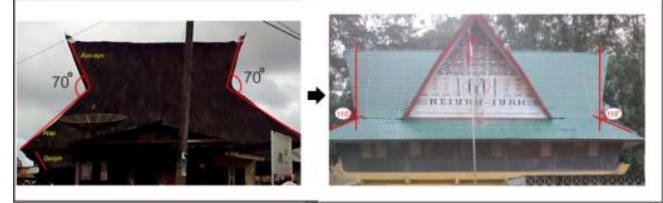

Gambar : Perbandingan kemiringan Pemasangan ayo-ayo (Dokumentasi Pribadi : Mhd. Try Adhitia)
Sudut kemiringan jauh melebihi $70^{\circ}$ Tentu saja ini tidak mencirikan kerendahan hati dalam menerima tamu jika dikaitkan dengan filosofi mengapa ayo-ayo dibuat miring atau menunduk pada rumah adat Karo yang asli.

\section{Perubahan Ornamen Ayo-ayo}

a. Ayo-ayo bagian depan

\begin{tabular}{|c|c|c|c|c|}
\hline No. & $\begin{array}{c}\text { Ornamen Pada } \\
\text { Bangunan Tahura }\end{array}$ & Ornamen Asli & $\begin{array}{l}\text { Nama } \\
\text { Ornamen }\end{array}$ & Keterangan \\
\hline 1. & & & $\begin{array}{l}\text { Bunga } \\
\text { gundur }\end{array}$ & $\begin{array}{l}\text { Masih terlihat } \\
\text { mirip dengan } \\
\text { sumber }\end{array}$ \\
\hline 2. & & & Raksasa & $\begin{array}{l}\text { Masih mirip, } \\
\text { tetapi ada } \\
\text { penambahan } \\
\text { bentuk yang } \\
\text { lumayan } \\
\text { mencolok }\end{array}$ \\
\hline 3. & & & $\begin{array}{l}\text { Tampune- } \\
\text { Tampune }\end{array}$ & $\begin{array}{l}\text { Masih terlihat } \\
\text { mirip, tetapi arah } \\
\text { serat anyaman } \\
\text { tidak logis }\end{array}$ \\
\hline 4. & & 葡 & $\begin{array}{c}\text { Embun } \\
\text { merkabun- } \\
\text { kabun }\end{array}$ & $\begin{array}{c}\text { Mirip, tetapi } \\
\text { mengalami } \\
\text { penyederhanaan } \\
\text { bentuk }\end{array}$ \\
\hline 5. & & & $\begin{array}{c}\text { Cekili } \\
\text { Kambing }\end{array}$ & $\begin{array}{l}\text { Mirip, tetapi } \\
\text { ornamen ini } \\
\text { biasanya di } \\
\text { tempatkan pada } \\
\text { mel-melen rumah } \\
\text { adat }\end{array}$ \\
\hline 6. & & 3 & $\begin{array}{c}\text { Pengeret- } \\
\text { ret }\end{array}$ & Masih mirip \\
\hline
\end{tabular}




\begin{tabular}{|c|c|c|c|c|}
\hline 7. & -2 & & $\begin{array}{l}\text { Baleng- } \\
\text { baleng }\end{array}$ & $\begin{array}{c}\text { Masih mirip, } \\
\text { tetapi } \\
\text { menghilangkan } \\
\text { salah satu } \\
\text { warnanya }\end{array}$ \\
\hline 8. & & - & - & $\begin{array}{c}\text { Tidak } \\
\text { terindetifikasi }\end{array}$ \\
\hline 9. & $8: 8$ & - & - & $\begin{array}{c}\text { Tidak } \\
\text { terindetifikasi }\end{array}$ \\
\hline 10. & atlin. & - & - & $\begin{array}{c}\text { Tidak } \\
\text { terindetifikasi }\end{array}$ \\
\hline 11. & Pin & - & - & $\begin{array}{c}\text { Tidak } \\
\text { terindetifikasi }\end{array}$ \\
\hline 12 . & {$\left[\begin{array}{l}18 \\
4\end{array}\right.$} & - & - & $\begin{array}{c}\text { Tidak } \\
\text { terindetifikasi }\end{array}$ \\
\hline
\end{tabular}

a. Ayo-ayo bagian belakang

\begin{tabular}{|c|c|c|c|c|}
\hline No. & $\begin{array}{c}\text { Ornamen } \\
\text { Pada } \\
\text { Bangunan } \\
\text { Tahura }\end{array}$ & Ornamen Asli & $\begin{array}{l}\text { Nama } \\
\text { Ornamen }\end{array}$ & Keterangan \\
\hline 1. & & & $\begin{array}{l}\text { Bunga } \\
\text { gundur }\end{array}$ & $\begin{array}{l}\text { Masih terlihat mirip } \\
\text { dengan sumber }\end{array}$ \\
\hline 2. & & & Raksasa & $\begin{array}{l}\text { Masih mirip, tetapi } \\
\text { ada penambahan } \\
\text { bentuk yang } \\
\text { lumayan mencolok }\end{array}$ \\
\hline 3. & & 毁 & $\begin{array}{l}\text { Tampune- } \\
\text { tampune }\end{array}$ & $\begin{array}{c}\text { Masih terlihat } \\
\text { mirip, tetapi arah } \\
\text { serat anyaman tidak } \\
\text { logis }\end{array}$ \\
\hline 4. & & 跑 & $\begin{array}{c}\text { Embun } \\
\text { merkabun- } \\
\text { kabun }\end{array}$ & $\begin{array}{c}\text { Mirip, tetapi } \\
\text { mengalami } \\
\text { penyederhanaan }\end{array}$ \\
\hline
\end{tabular}




\begin{tabular}{|c|c|c|c|c|}
\hline & & & & bentuk \\
\hline 5. & & & $\begin{array}{c}\text { Cekili } \\
\text { kambing }\end{array}$ & $\begin{array}{c}\text { Mirip, tetapi } \\
\text { ornamen ini } \\
\text { biasanya di } \\
\text { tempatkan pada } \\
\text { mel-melen rumah } \\
\text { adat }\end{array}$ \\
\hline 6. & $\sum_{1}^{*} 888$ & 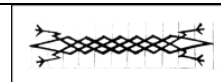 & Pengeret-ret & Masih mirip \\
\hline 7. & & E्ב & $\begin{array}{l}\text { Baleng- } \\
\text { baleng }\end{array}$ & $\begin{array}{c}\text { Masih mirip, tetapi } \\
\text { menghilangkan } \\
\text { salah satu } \\
\text { warnanya }\end{array}$ \\
\hline 8. & & - & - & $\begin{array}{c}\text { Tidak } \\
\text { terindetifikasi }\end{array}$ \\
\hline 9. & & - & - & $\begin{array}{c}\text { Tidak } \\
\text { terindetifikasi }\end{array}$ \\
\hline 10. & Allith & - & - & $\begin{array}{c}\text { Tidak } \\
\text { terindetifikasi }\end{array}$ \\
\hline 11. & & - & - & $\begin{array}{c}\text { Tidak } \\
\text { terindetifikasi }\end{array}$ \\
\hline 12. & 8 & - & - & $\begin{array}{c}\text { Tidak } \\
\text { terindetifikasi }\end{array}$ \\
\hline
\end{tabular}

b. Ayo-ayo bagian kiri

\begin{tabular}{|l|c|c|l|l|}
\hline No. & $\begin{array}{c}\text { Ornamen Pada } \\
\text { Bangunan Tahura }\end{array}$ & Ornamen Asli & $\begin{array}{l}\text { Nama } \\
\text { Ornamen }\end{array}$ & Keterangan \\
\hline 1. & & Bunga & $\begin{array}{l}\text { Masih terlihat } \\
\text { mirip, tetapi } \\
\text { penekanan warna } \\
\text { berubah }\end{array}$ \\
\hline 2. & & & $\begin{array}{l}\text { Embun } \\
\text { sikawiten }\end{array}$ & $\begin{array}{l}\text { Bentuknya } \\
\text { disederhakan dan } \\
\text { bidang kosong } \\
\text { tidak diisi, tetapi }\end{array}$ \\
\hline
\end{tabular}




\begin{tabular}{|c|c|c|c|c|}
\hline & & & & $\begin{array}{l}\text { masih ada } \\
\text { kemiripan }\end{array}$ \\
\hline 3. & & & Raksasa & $\begin{array}{l}\text { Mirip dengan } \\
\text { sumber tetap } \\
\text { bentuknya } \\
\text { disederhanakan }\end{array}$ \\
\hline 4. & & 宣 & $\begin{array}{c}\text { Baleng- } \\
\text { baleng }\end{array}$ & $\begin{array}{l}\text { Masih terlihat } \\
\text { mirip tetapi } \\
\text { disederhanakan }\end{array}$ \\
\hline 5. & & 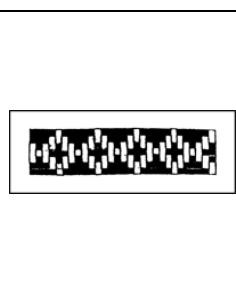 & $\begin{array}{c}\text { Anjak-anjak } \\
\text { beru } \\
\text { Ginting }\end{array}$ & $\begin{array}{l}\text { Masih ada } \\
\text { kemiripan } \\
\text { walaupun } \\
\text { penekanan warna } \\
\text { berbeda }\end{array}$ \\
\hline 6. & & 年 & $\begin{array}{c}\text { Pengeret- } \\
\text { ret }\end{array}$ & $\begin{array}{l}\text { Mirip tetapi terjadi } \\
\text { distorsi bentuk } \\
\text { pada kaki }\end{array}$ \\
\hline 7. & & 나담 & $\begin{array}{c}\text { Piseren } \\
\text { Kambing }\end{array}$ & $\begin{array}{l}\text { Mirip tetapi } \\
\text { mengalami } \\
\text { penyederhanaan } \\
\text { bentuk }\end{array}$ \\
\hline 8. & & - & - & $\begin{array}{c}\text { Tidak } \\
\text { teridentifkasi }\end{array}$ \\
\hline 9. & & - & - & $\begin{array}{c}\text { Tidak } \\
\text { teridentifkasi }\end{array}$ \\
\hline 10. & & - & - & $\begin{array}{c}\text { Tidak } \\
\text { teridentifkasi }\end{array}$ \\
\hline 11. & $a^{2}+y^{2}$ & - & - & $\begin{array}{c}\text { Tidak } \\
\text { teridentifkasi }\end{array}$ \\
\hline
\end{tabular}

\section{c. Ayo-ayo bagian kanan}

\begin{tabular}{|l|c|c|c|c|}
\hline No. & $\begin{array}{c}\text { Ornamen Pada } \\
\text { Bangunan Tahura }\end{array}$ & Ornamen Asli & $\begin{array}{l}\text { Nama } \\
\text { Ornamen }\end{array}$ & Keterangan \\
\hline 1. & $\Leftrightarrow$ & Bunga & Masih terlihat \\
mirip, tetapi
\end{tabular}




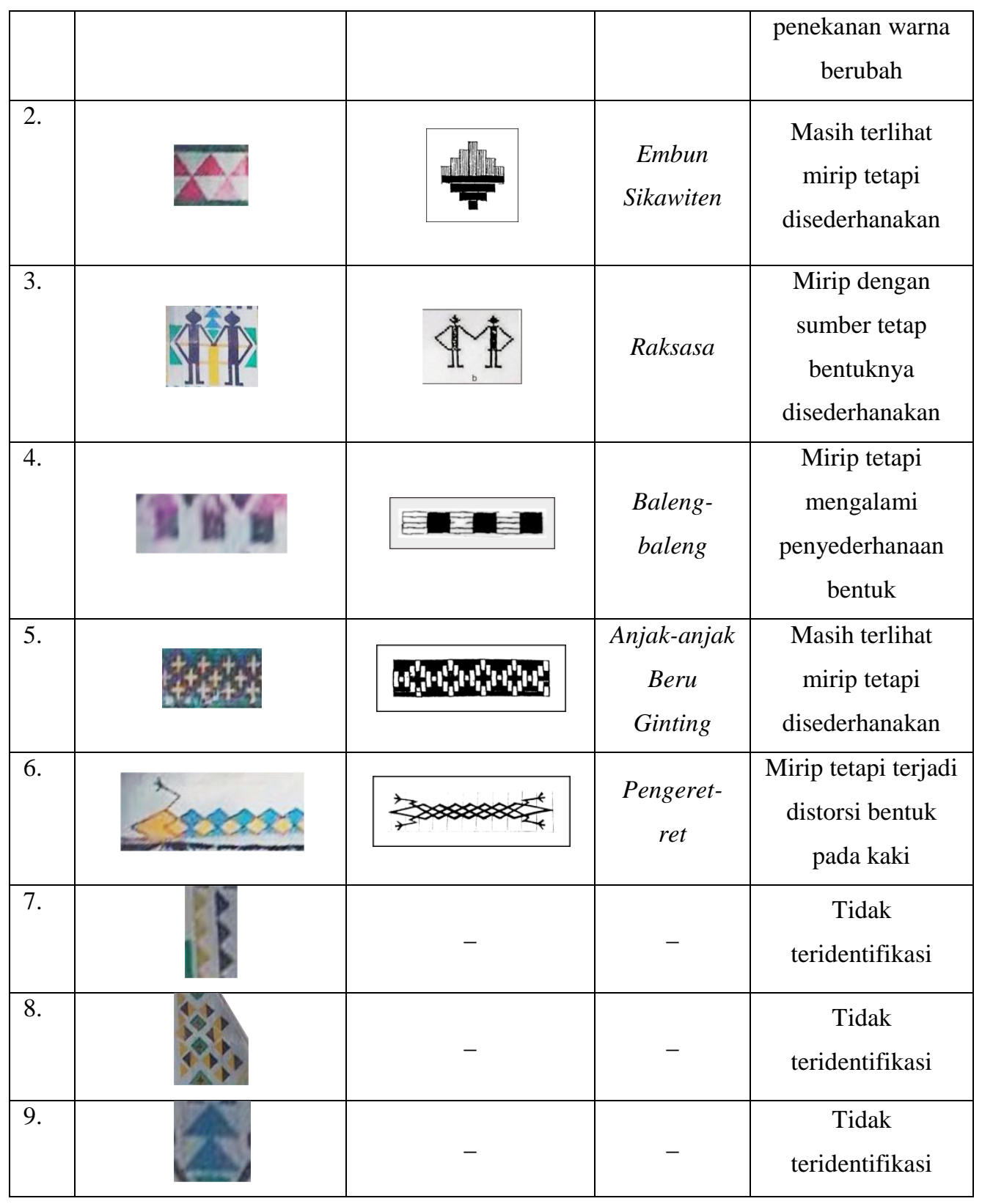




\section{Perubahan Warna Pada Ayo-ayo}

Depan

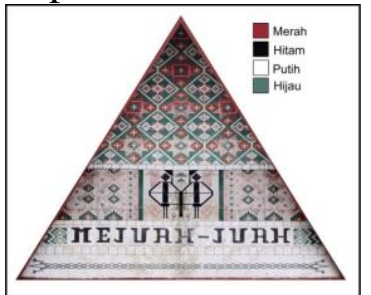

Belakang
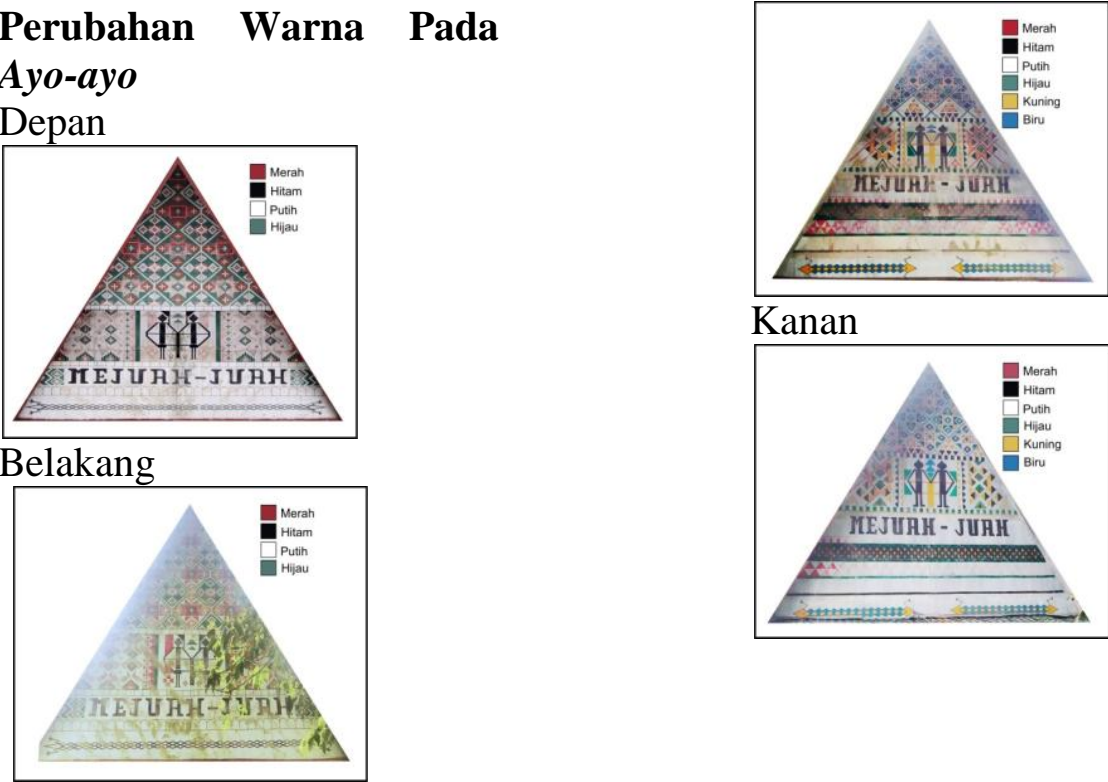

Kanan

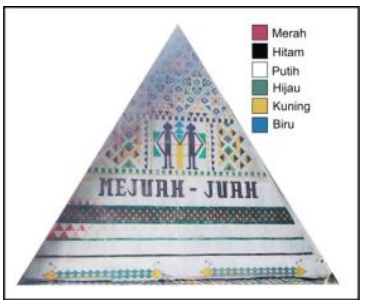

Kiri

B. Tanggapan Masyarakat Karo di Berastagi Terhadap Perubahan Ayo-ayo Pada Bangunan Objek Wisata Tahura

\begin{tabular}{|c|l|c|c|c|}
\hline No. & \multicolumn{1}{|c|}{ Nama } & Setuju & Tidak Setuju & Strata \\
\hline 1 & M.J. Uda Ginting & - & $\checkmark$ & Pemuka adat \\
\hline 2 & Sofian Tarigan & - & $\checkmark$ & Pemuka adat \\
\hline 3 & Suardi & - & $\checkmark$ & Pemuka adat \\
\hline 4 & Dra. Esther Sinuraya & - & $\checkmark$ & Pemerintah \\
\hline 5 & Kasman Sembiring, SH. & - & $\checkmark$ & Pemerintah \\
\hline 6 & Suparmanta Surbakti & - & $\checkmark$ & Pemerintah \\
\hline 7 & Kriswanto Ginting & - & $\checkmark$ & Pemerhati Seni \\
\hline 8 & Bahagia Ginting & - & $\checkmark$ & Pemerhati Seni \\
\hline 9 & Horas Parlindungan Siringgo- & - & $\checkmark$ & Seniman \\
\hline 10 & Iringgo & - & $\checkmark$ & Seniman \\
\hline 11 & Depi Tarigan, S.Pd & - & $\checkmark$ & Seniman \\
\hline 12 & Destanta Permana, S.Pd. & - & $\checkmark$ & Pendidikan \\
\hline 13 & Drs. Nurdin & $\checkmark$ & - & Pendidikan \\
\hline 14 & Daniel Ginting & $\checkmark$ & - & Organisasi \\
\hline 15 & Natal Prima Ginting & - & $\checkmark$ & Organisasi \\
\hline 16 & Datya Thresia G. & - & $\checkmark$ & Komunitas \\
\hline 17 & Darta Boni Vasius Surbakti & - & $\checkmark$ & Komunitas \\
\hline 18 & Eywandy Tarigan & $\checkmark$ & Masyarakat Umum \\
\hline 19 & Aria Karma Surbakti & $\checkmark$ & Masyarakat Umum \\
\hline 20 & Boy Sanjaya Ginting & - & $\checkmark$ & $\checkmark$ \\
\hline
\end{tabular}

Ayo-ayo pada bangunan

Tahura menjadi salah satu bentuk perubahan yang sangat ekstrim. Warna yang tidak konsisten, bentuk ornamen yang mengalami penambahan taupun penyederhanaan bentuk yang dianggap terlalu jauh perubahannya, membuat 18 (delapan 
Belas) responden menyatakan peubahan ayo-ayo pada bangunan Tahura memberi dampak buruk bagi penegetahuan masyarakat Karo sendiri ataupun masyarakat luas.

Lain halnya dengan 2 (dua) responden lainnya yang beranggapan perubahan yang terjadi pada bangunan Tahura merupakan bentuk inovasi yang membuat ayo-ayo itu sendiri lebih menarik dari segi warna dan bentuk ornamen. Lebih moderen dengan apa yang dulu ditampilkan, yang hanya memakai beberapa warna saja. Ayo-ayo harus beradaptasi dengan selera masyarakat sekarang, dibuat dengan warna beragam dan mencolok.

\section{KESIMPULAN}

Ayo-ayo pada bangunan Tahura merupakan contoh ayo-ayo yang telah mengalami banyak perubahan. Perubahan terjadi dimulai dari bahan yang digunakan, warna, dan ornamen. Sebagian besar masyarakat Karo tidak setuju dengan ayo-ayo di Tahura tersebut, karena tidak lagi mencirikan ayo-ayo khas Karo. Yang ditinggalkan disana hanya hiasan saja tetapi itu juga tidak memiliki kualitas yang bagus, seperti hanya sekedar saja.

Ditemukan kesepahaman pendapat penulis dengan pendapat yang telah diterima dari masyarakat Karo, yang menjadi penguatan materi bahasan hasil penelitian. Bahwa memang benar adanya perubahan yang terjadi pada ayo-ayo Tahura mulai dari segi bentuk dasar, sudut kemiringan, warna, dan ornamen.

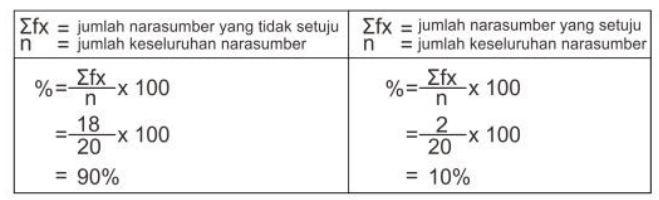

Sehingga dapat dipresentasikan, 90\% masyarakat tidak menerima perubahan ayo-ayo dan $10 \%$ menerima perubahan ayoayo yang terjadi pada bangunan Tahura.

\section{SARAN}

1. Memotivasi masyarakat Karo untuk melestarikan arsitektur tradisional Karo, meskipun hanya megadopsi sebagian dari rumah adat Karo seperti ayo-ayo dan menjaga keutuhan budaya Karo.

2. Sebaiknya generasi muda sekarang lebih mencintai budayanya sendiri. Budaya Karo ini haruslah digali pengetahuannya agar masyarakat luas mengetahui kekayaannya. Dengan ini, akan menimbulkan kepedulian untuk saling menjaga dan melestarikan budaya Karo.

3. Guru-guru disekolah lebih memperhatikan mata pelajaran budaya Karo yang diampunya. Sehingga pembelajaran budaya Karo lebih bisa dipahami dan dicintai. Siswa sebagai generasi muda hendaknya mempelajari budaya Karo agar tetap lestari.

4. Untuk mahasiswa agar terus meneliti budaya Karo untuk 
sumber-sumber bacaan generasi berikutnya tetap ada dan semakin luas.

\section{DAFTAR PUSTAKA}

Arikunto, Suharsimi. 2006. Prosedur Penelitian. Medan: Rineka Cipta.

Bangun, Sem C. 2001. Kritik Seni Rupa. Bandung: ITB Bandung.

Sinulingga, Desnalri. 2006.

Aktualisasi Ornamen Ayoayo Pada Bangunan

Arsitektur Modern Di Kabupaten Karo. Medan. Skripsi UNIMED

Sirait, Baginda. 1984. Tinjauan Seni Dan Apresiasi. Medan: Percetakan Offset : Bali" Medan. .1984. Design Ornament Tradisional Daerah Sumatera Utara.

Medan: Percetakan Offset "Bali" Medan.

Sitepu, A.G. 1997. Ragam Hias (Ornamen) Tradisional Karo Seri-A. Kabanjahe:

Sugiyono. 2010. Metode Penelitian Kualitatf, Kuantitatif dan $R \& D$. Bandung: Alfabeta.

Prinst, Darwan. 1996. Adat Karo. Medan: Kongres Kebudayaan Karo 